Araștırma ve Geliștirme Dergisi

International Journal of

Engineering Research and

Development
UMAGD, (2021) 13(2), 750-762.

10.29137/umagd.882607

Cilt/Volume:13 Sayı/Issue:2 Haziran/June 2021

Araştırma Makalesi / Research Article

\title{
Usage of Waste Water Treatment Plants Hydroelectric Energy for Urban Lighting Energy: The Case of Turkey
}

\author{
Burhan Baran 1 \\ ${ }^{I}$ Department of Electrical and Electronic Engineering, Inonu University, Malatya, TURKEY
}

Başvuru/Received: 21/04/2021

Kabul / Accepted: 10/06/2021

Çevrimiçi Basım / Published Online: 18/06/2021

Son Versiyon/Final Version: 18/06/2021

\begin{abstract}
In this study, primarily from wastewater treatment plants in seven geographical regions in Turkey value of electrical power that can be generated were calculated. Then, a study was carried out to determine the ratio of the electrical power generated to meet the lighting energy requirement in the relevant geographical region. For this purpose, a method for evaluating the hydroelectric potential of wastewater treatment plant was presented. For seven geographical regions, population prediction in 2018-2025, predicted flow rate of wastewater to be treated from wastewater treatment plant and lighting consumption for each region were predicted. Predictions for the future years were made by using the equations obtained through the curve fitting algorithm written in Matlab environment. Using these values, the predicted electrical power values were calculated in case the distance between the treated wastewater falls and the turbine where electricity generation took place was 3 meters. According to study total predicted wastewater would be 4.16 (2018) and 5.89 (2025) billion $\mathrm{m}^{3}$. Total cities' predicted lighting energy consumption in Turkey would be 4429.2 GWh (2018) and 4941.5 GWh (2025). And yearly predicted electricity generation from wastewater treatment plant hydroelectric would be $28.51 \mathrm{GWh}(2018)$ and $38.53 \mathrm{GWh}(2025)$.
\end{abstract}

\section{Key Words}

"Distributed Generation, Lighting Energy, Micro Hydroelectric, Waste Water" 


\section{Introduction}

Global demand for electrical energy is constantly increasing. The trend in the world is that the demand for electrical energy in developing countries is increasing faster than supply (Nimje and Dhanjode, 2015). The main reasons for the increase in demand faster than supply can be shown as population growth, climate change, economic development and increasing electricity energy deficit. In order to meet this energy deficit, it may be possible to provide renewable energy sources such as wind, solar, biomass and hydro, which are free and abundant in nature. In the hydrological cycle, atmospheric water reaches the earth's surface as precipitation. Besides the water resources, the water supplied from the clean water sources are discharged as domestic wastewater after being used for humanistic needs (Hydroelectric-4, 2019, Baran, 2019).

There are two types of energy in running water. One is kinetic energy, the other is potential energy. Depending on the type of hydraulic plants, one of these two energy types is used to generate electricity. The incoming water falls on the blades of the turbine which can make the rotation. Electrical energy is generated by rotating the electric generators where the shaft of the turbine is generated. The generated electrical energy is then transmitted to the transformers to be connected to the main grid (Hydroelectric-3, 2019). Hydroelectric power plants are classified according to the size of the electrical power they generate. Large power plants can generate between $30 \mathrm{MW}$ and $100 \mathrm{MW}$. Small hydroelectric plants can generate power between $100 \mathrm{~kW}$ to $1 \mathrm{MW}$. Moreover, microhydroelectric power plants can generate electricity between $5 \mathrm{~kW}$ and $100 \mathrm{~kW}$. The smallest hydropower plants are pico-hydropower plants capable of generating a maximum of $5 \mathrm{~kW}$ (Yah et al., 2017). Micro-hydroelectric turbines are generally used in the generation of electricity from the discharged wastewater of wastewater treatment plants.

Numerous works associated with hydroelectric from wastewater treatment plant. A study by Bousquet et al. (2017) had presented a method to assess the hydroelectric potential of wastewater treatment plants. They had developed a two-step algorithm. The first stage included the prediction of the annual electricity consumption in the selected region and the second stage the studies on the feasibility of each plan considering the investment costs and local electricity sales. At the end of the study, nineteen regions with a total of 9.3 GWh/year energy generation potential were identified. Ak et al. (2017) had aimed to find the most suitable sustainable hydroelectric technology. A total of six criteria were evaluated, including investment cost, repayment period, power generation performance, construction time and ventilation capacity. With the fuzzy logic tool, the satisfaction of each criterion was estimated separately. In the study had conducted by Gu et al. (2017) energy consumption and recovery in wastewater treatment plants were analyzed. The differences between the self-sufficiency of the energy generated in wastewater treatment plants in different regions around the world and the current energy consumption were analyzed. In the study had conducted by Zhou et al. (2017) potential regions, turbine selection and project costs for very low head energy sources were investigated. The performance of a newly designed micro-hydroelectric system for wastewater treatment plants with large fluctuations in flow was measured by Chae et al. (2015) As a result of the test, it was found that the new system obtained 1.78-22.80 times more electricity at both flow rate and net height. In the study had conducted by Power et al. (2014) an evaluation method was developed to estimate the potential power outputs and the payback times of the hydroelectric energy recovery programs. A sensitivity analysis was performed to demonstrate the effect of changes in current, turbine selection and electricity prices on power output. In the study had conducted by Kose et al. (2013) a hybrid system consisting of wind and hydroelectric power plants was analyzed to meet the energy demand of Konya water treatment plant. In addition to $250 \mathrm{~kW}$ HEPP and $250 \mathrm{~kW}$ WPP, two $250 \mathrm{~kW}$ or one $500 \mathrm{~kW}$ wind turbines were added to the HEPP in order to meet the electrical energy requirements of the Kony a water treatment plant. In this case, the energy demand of the power plant could be met with HEPP for 10 months per year. It had concluded that a WPP was required to provide uninterrupted energy. In the study conducted by Frijns et al. (2013) municipal wastewater was evaluated as a source of chemical energy. A study was conducted by Kollmann et al. (2017) on the supply of surplus energy in wastewater treatment plants to the main distribution network to supply to external consumers. Tamrakar et al. (2015) had conducted a study on the applicability of micro hydroelectric power plant to domestic needs. With the simulations, suggestions had been made regarding the applicability of small hydroelectric power plants to domestic. Berger et al. (2013) had conducted a study on the constraints that should be taken into account, especially for small hydropower plants for energy recovery and storage of energy. The results had showed that some sewer structures may be suitable for energy recovery. In a study by Abbas et al. (2018) a study was conducted to assess how much savings would be achieved if a hydro turbine was used in a wastewater treatment plant. For this purpose, a computational fluid dynamics software was applied. As a result, savings were estimated to be 1,564 MWh/year.

In this study, considering all wastewater treatment plants in Turkey, a study had been made with the energy that could be obtained from these meets the lighting energy demand of all cities. Firstly, predicted amount of electrical energy that could be derived from wastewater treatment plants located in seven geographical regions of Turkey were calculated. Then, the predicted amounts of electricity consumed in the province lighting in the same regions were calculated. A prediction study was carried out on the extent to which this generation would meet the demand energy of the province lighting. For this purpose, population, treated wastewater amount and consumed lighting energy values for each region up to 2018 were obtained from Turkey Statistical Institute (TUIK) and Republic of Turkey Energy Market Regulatory Authority (EPDK). These data until 2025 were predicted by using curve fitting program written in Matlab environment. According to these flow rates, the total micro-hydroelectric energy values which could be generated from wastewater treatment plants with a height of 3 meters were calculated. By using these predicted values, the ratio of micro-hydroelectric generation obtained from wastewater treatment plants to province lighting electricity consumption was calculated for each region. In this study, unlike other studies, the curve fitting method written in Matlab environment was used to obtain predicted values of population, treated wastewater and lighting energy consumption parameters. In addition, a study was conducted on the use of electrical 
energy to be obtained from treated wastewater in urban lighting. The wastewater from wastewater treatment plants is generally discharged directly to the receiving environment without being used for any other purpose. With this study, it was thought that this wastewater, which was discharged into the receiving environment, would guide local administrations in terms of giving an idea about the use of lighting energy of cities.

The next part of the study after this stage consists of four parts. The second section is the materials and method section. In this section, curve fitting method was explained. Predicting of population, treated wastewater and lighting consumption energy were made for seven geographic regions. The third section is the results and discussion section, and the electrical energy calculations that could be generated from wastewater had been made for 3 meters head height. In addition, the ratio of these energies to meet the lighting energy consumption of each region had been predicted. In the conclusion section, the results obtained in the study were compared.

\section{Materials and Method}

\subsection{Curve Fitting}

The data generated in experimental studies are generally point-based. A continuous function cannot be obtained. In this case the data is given as point pairs with $\left(\mathrm{x}_{1}, \mathrm{y}_{1}\right), \ldots,\left(\mathrm{x}_{\mathrm{n}}, \mathrm{y}_{\mathrm{n}}\right)$. Curve fitting is the function that gives the least incorrect curve in distance to the current values (Curve Fitting, 2018). This method is intended to find an appropriate curve equation that best represents the relationship between the two variables. In this study, polynomial equations were obtained by using the curve fitting algorithm which was written in Matlab environment and using the current population (2007-2018), the amount of treated wastewater (2001-2016) and lighting energy consumption values (2000-2017) of seven geographical regions has taken from TUIK (TUIK, 2019). With these equations, predictions were made between 2018 and 2025 of population, consumption of wastewater and lighting energy consumption values. The general steps of the program in Matlab environment for obtaining the predicted values were as Figure 1:

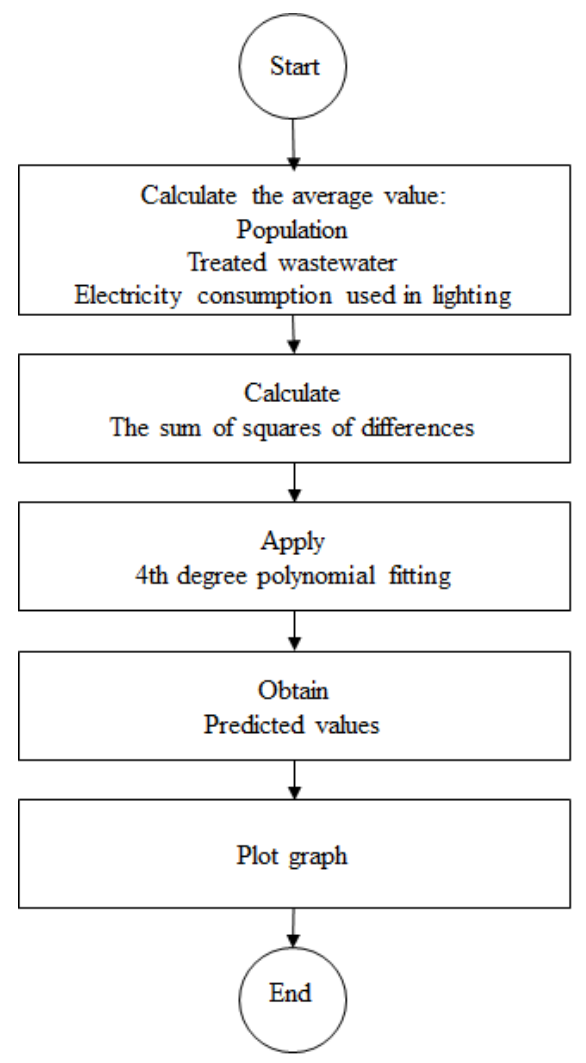

Figure 1. Flowchart used to obtain predicted values 


\subsection{Population}

Turkey has seven geographical regions. When the first part of population values (2007-2018) in Table 2 were entered into the curve fitting algorithm created in Matlab environment for seven geographic regions, the graphs were obtained as in Figure 2.

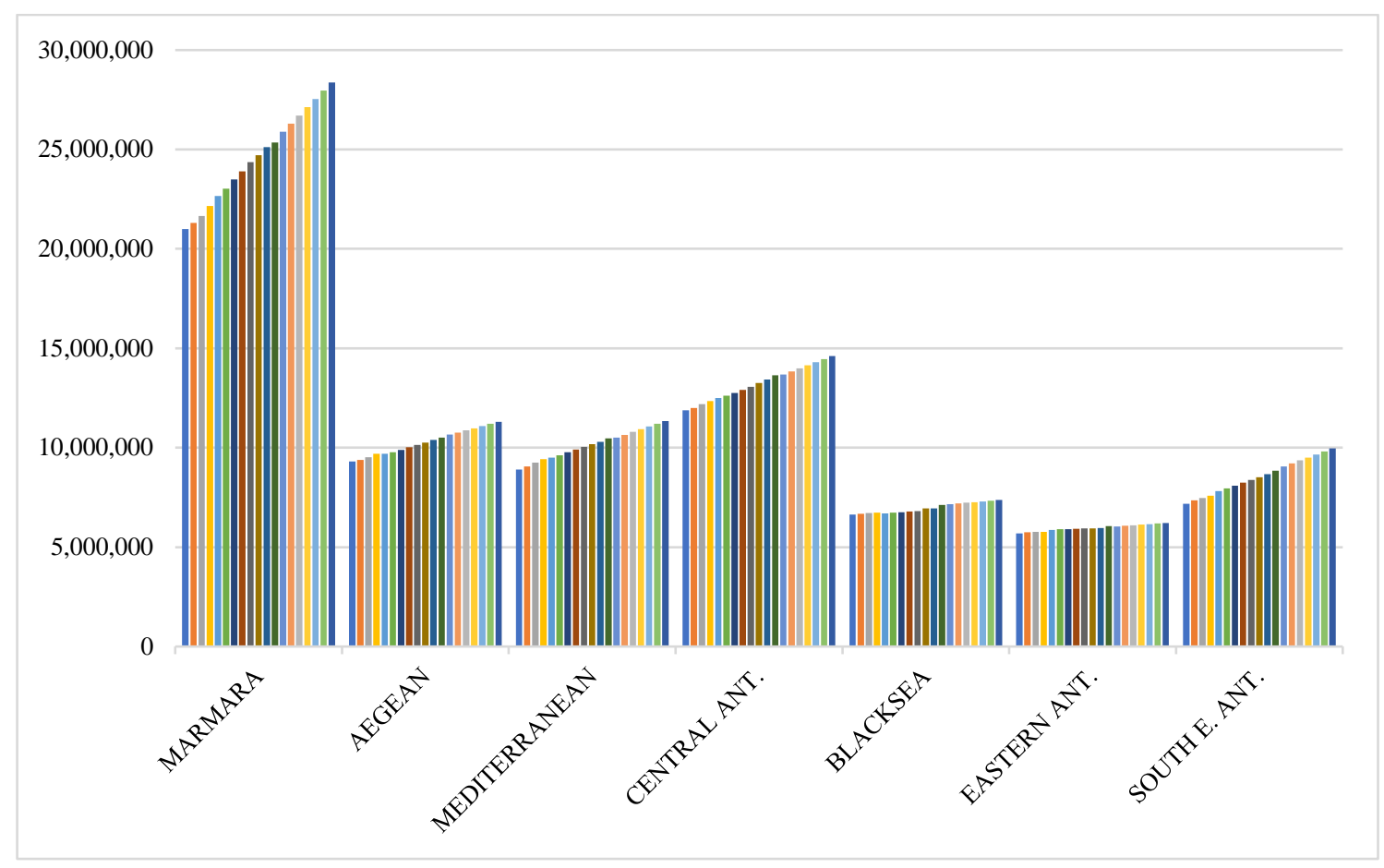

Figure 2. Population results of curve fitting for seven geographic region

Population equations by year for each region and the R-squared values obtained were as in Table 1.

Table 1. Population equations by year for each region and the R-squared values

\begin{tabular}{ccc}
\hline Region & Population Equation (by year) & R-square \\
\hline Marmara & $4.149 \times 10^{5} \times$ year- $8.118 \times 10^{8}$ & 0.9974 \\
Aegean & $1.082 \times 10^{5} \times$ year- $2.078 \times 10^{8}$ & 0.9915 \\
Mediterranean & $1.376 \times 10^{5} \times$ year- $2.673 \times 10^{8}$ & 0.9968 \\
Central Anatolian & $1.565 \times 10^{5} \times$ year- $3.023 \times 10^{8}$ & 0.9965 \\
Black Sea & $3.530 \times 10^{4} \times$ year- $6.411 \times 10^{7}$ & 0.8107 \\
East Anatolian & $2.878 \times 10^{4} \times$ year- $5.206 \times 10^{7}$ & 0.9317 \\
Southeast Anatolian & $1.504 \times 10^{5} \times$ year- $2.946 \times 10^{8}$ & 0.9982 \\
\hline
\end{tabular}

By using these equations, when the population predicts were made between 2019 and 2025 for each region separately, the values in the second part (2019-2025) of Table 2 were obtained. While values between 2007 and 2018 were the current population values, the values between 2019 and 2025 were predicted population values.

Table 2. Current and predicted population values of seven geographic regions between 2007 and 2025 (TUIK, 2019)

\begin{tabular}{ccccccccc}
\hline Years & Marmara & Aegean & Mediterranean & $\begin{array}{c}\text { Central } \\
\text { Anatolian }\end{array}$ & $\begin{array}{c}\text { Black } \\
\text { Sea }\end{array}$ & $\begin{array}{c}\text { Eastern } \\
\text { Anatolian }\end{array}$ & $\begin{array}{c}\text { South } \\
\text { Eastern } \\
\text { Anatolian }\end{array}$ & Turkey \\
\hline 2007 & 20995367 & 9299322 & 8906427 & 11877503 & 6642206 & 5694582 & 7170849 & 70586256 \\
2008 & 21313665 & 9384848 & 9050691 & 12004736 & 6668165 & 5744243 & 7350752 & 71517100 \\
2009 & 21655690 & 9517153 & 9252902 & 12187872 & 6723050 & 5761752 & 7462893 & 72561312 \\
2010 & 22158568 & 9693594 & 9423231 & 12346517 & 6733081 & 5775225 & 7592772 & 73722988 \\
\hline
\end{tabular}


Table 2 (cont.). Current and predicted population values of seven geographic regions between 2007 and 2025 (TUIK, 2019)

\begin{tabular}{ccccccccc}
\hline Years & Marmara & Aegean & Mediterranean & $\begin{array}{c}\text { Central } \\
\text { Anatolian }\end{array}$ & $\begin{array}{c}\text { Black } \\
\text { Sea }\end{array}$ & $\begin{array}{c}\text { Eastern } \\
\text { Anatolian }\end{array}$ & $\begin{array}{c}\text { South } \\
\text { Eastern } \\
\text { Anatolian }\end{array}$ & Turkey \\
\hline 2011 & 22663679 & 9687692 & 9495788 & 12500220 & 6697209 & 5863508 & 7816173 & 74724269 \\
2012 & 23024533 & 9779502 & 9611007 & 12610403 & 6736786 & 5906680 & 7958473 & 75627384 \\
2013 & 23486223 & 9897313 & 9766093 & 12758430 & 6756889 & 5906564 & 8096352 & 76667864 \\
2014 & 23892868 & 10023549 & 9906771 & 12908583 & 6785785 & 5927630 & 8250718 & 77695904 \\
2015 & 24357131 & 10138132 & 10039939 & 13070497 & 6808188 & 5941626 & 8385540 & 78741053 \\
2016 & 24715319 & 10265111 & 10182776 & 13258256 & 6945732 & 5938790 & 8508887 & 79814871 \\
2017 & 2519207 & 10383963 & 10303984 & 13424410 & 6951130 & 5962666 & 8665165 & 80810525 \\
2018 & 25346380 & 10514200 & 10461409 & 13650496 & 7124918 & 6058499 & 8847980 & 82003882 \\
$\mathbf{2 0 1 9}$ & $\mathbf{2 5 8 8 3 1 0 0}$ & $\mathbf{1 0 6 5 5 8 0 0}$ & $\mathbf{1 0 5 1 4 4 0 0}$ & $\mathbf{1 3 6 7 3 5 0 0}$ & $\mathbf{7 1 6 0 7 0 0}$ & $\mathbf{6 0 4 6 8 2 0}$ & $\mathbf{9 0 5 7 6 0 0}$ & $\mathbf{8 2 9 9 1 9 2 0}$ \\
$\mathbf{2 0 2 0}$ & $\mathbf{2 6 2 9 8 0 0 0}$ & $\mathbf{1 0 7 6 4 0 0 0}$ & $\mathbf{1 0 6 5 2 0 0 0}$ & $\mathbf{1 3 8 3 0 0 0 0}$ & $\mathbf{7 1 9 6 0 0 0}$ & $\mathbf{6 0 7 5 6 0 0}$ & $\mathbf{9 2 0 8 0 0 0}$ & $\mathbf{8 4 0 2 3 6 0 0}$ \\
$\mathbf{2 0 2 1}$ & $\mathbf{2 6 7 1 2 9 0 0}$ & $\mathbf{1 0 8 7 2 2 0 0}$ & $\mathbf{1 0 7 8 9 6 0 0}$ & $\mathbf{1 3 9 8 6 5 0 0}$ & $\mathbf{7 2 3 1 3 0 0}$ & $\mathbf{6 1 0 4 3 8 0}$ & $\mathbf{9 3 5 8 4 0 0}$ & $\mathbf{8 5 0 5 5 2 8 0}$ \\
$\mathbf{2 0 2 2}$ & $\mathbf{2 7 1 2 7 8 0 0}$ & $\mathbf{1 0 9 8 0 4 0 0}$ & $\mathbf{1 0 9 2 7 2 0 0}$ & $\mathbf{1 4 1 4 3 0 0 0}$ & $\mathbf{7 2 6 6 6 0 0}$ & $\mathbf{6 1 3 3 1 6 0}$ & $\mathbf{9 5 0 8 8 0 0}$ & $\mathbf{8 6 0 8 6 9 6 0}$ \\
$\mathbf{2 0 2 3}$ & $\mathbf{2 7 5 4 2 7 0 0}$ & $\mathbf{1 1 0 8 8 6 0 0}$ & $\mathbf{1 1 0 6 4 8 0 0}$ & $\mathbf{1 4 2 9 9 5 0 0}$ & $\mathbf{7 3 0 1 9 0 0}$ & $\mathbf{6 1 6 1 9 4 0}$ & $\mathbf{9 6 5 9 2 0 0}$ & $\mathbf{8 7 1 1 8 6 4 0}$ \\
$\mathbf{2 0 2 4}$ & $\mathbf{2 7 9 5 7 6 0 0}$ & $\mathbf{1 1 1 9 6 8 0 0}$ & $\mathbf{1 1 2 0 2 4 0 0}$ & $\mathbf{1 4 4 5 6 0 0 0}$ & $\mathbf{7 3 3 7 2 0 0}$ & $\mathbf{6 1 9 0 7 2 0}$ & $\mathbf{9 8 0 9 6 0 0}$ & $\mathbf{8 8 1 5 0 3 2 0}$ \\
$\mathbf{2 0 2 5}$ & $\mathbf{2 8 3 7 2 5 0 0}$ & $\mathbf{1 1 3 0 5 0 0 0}$ & $\mathbf{1 1 3 4 0 0 0 0}$ & $\mathbf{1 4 6 1 2 5 0 0}$ & $\mathbf{7 3 7 2 5 0 0}$ & $\mathbf{6 2 1 9 5 0 0}$ & $\mathbf{9 9 6 0 0 0 0}$ & $\mathbf{8 9 1 8 2 0 0 0}$ \\
\hline
\end{tabular}

According to the data in Table 2, the population growth rate from 2018 to 2025 had been predicted $11.94 \%$ in Marmara Region, $7.52 \%$ in Aegean Region, 8.40\% in Mediterranean Region, 7.05\% in Central Anatolia Region, 3.48\% in Black Sea Region, 2.66\% in Eastern Anatolia Region and $12.57 \%$ in Southeast Anatolia Region and $8.75 \%$ in Turkey. It had been predicted that the highest population growth rate would be in Southeastern Anatolia Region and the lowest population growth rate would be in Eastern Anatolia Region.

\subsection{Treated Wastewater}

Similarly, when the first part of wastewater values (2001-2016) in Table 4 were entered into the curve fitting algorithm created in Matlab environment for seven geographic regions, the graphs, polynomial equations and R-square values for each region were obtained as in Figure 3.

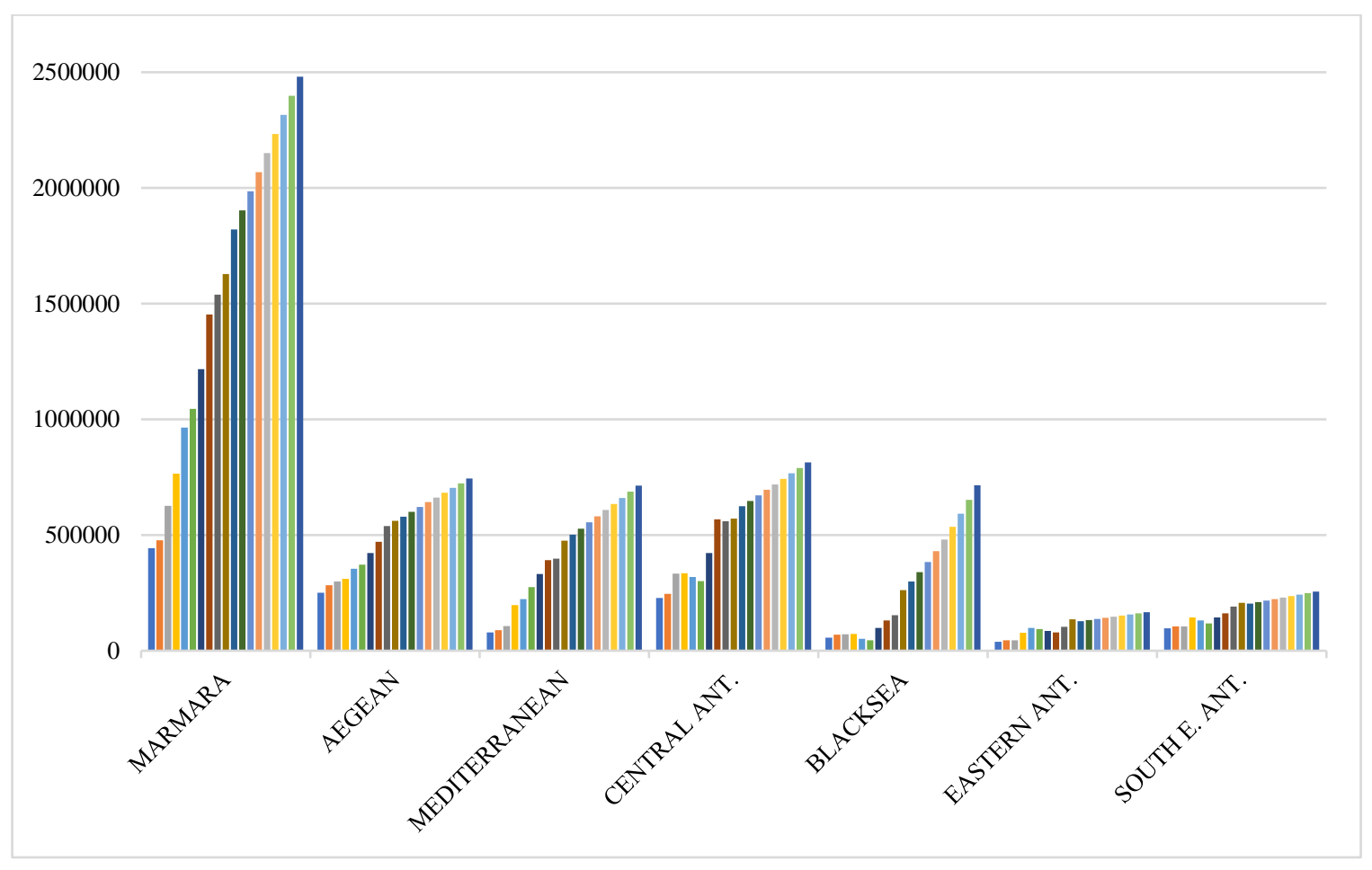

Figure 3. Treated wastewater results of curve fitting for seven geographic region 
Treated wastewater equations by year for each region and the R-squared values obtained were as in Table 3 .

Table 3. Treated wastewater equations by year for each region and the R-squared values

\begin{tabular}{ccc}
\hline Region & Treated Wastewater Equation $($ by year) & R-square \\
\hline Marmara & $8.241 \times 10^{4} \times$ year- $1.644 \times 10^{8}$ & 0.9819 \\
Aegean & $2.058 \times 10^{4} \times$ year- $4.093 \times 10^{7}$ & 0.9874 \\
Mediterranean & $2.655 \times 10^{4} \times$ year- $5.305 \times 10^{7}$ & 0.9782 \\
Central Anatolian & $2.375 \times 10^{4} \times$ year- $4.728 \times 10^{7}$ & 0.8678 \\
Black Sea & $1641 \times(\text { year })^{2}-6.581 \times 10^{6} \times$ year +6598114482 & 0.9377 \\
East Anatolian & $5002 \times$ year- $9.962 \times 10^{6}$ & 0.7482 \\
Southeast Anatolian & $6566 \times$ year- $1.304 \times 10^{7}$ & 0.8520 \\
\hline
\end{tabular}

Predictions of treated wastewater from Turkey's seven geographical regions of the 2017-2025 year has been made. While making these predicts, the equations in Figure 3 were used. The values obtained were as in Table 4. While the values between 2001 and 2016 indicate the current treated wastewater values, the values between 2017 and 2025 indicate the wastewater values to be predicted.

Table 4. Current and predicted flow rates (thousand $\mathrm{m}^{3} / \mathrm{year}$ ) (TUIK, 2019)

\begin{tabular}{cccccccc}
\hline Years & Marmara & Aegean & Mediterranean & $\begin{array}{c}\text { Central } \\
\text { Anatolian }\end{array}$ & $\begin{array}{c}\text { Black } \\
\text { Sea }\end{array}$ & $\begin{array}{c}\text { Eastern } \\
\text { Anatolian }\end{array}$ & $\begin{array}{c}\text { South } \\
\text { Eastern } \\
\text { Anatolian }\end{array}$ \\
\hline 2001 & 443997 & 250993 & 78701 & 227225 & 56608 & 39177 & 97274 \\
2002 & 476610 & 282251 & 88961 & 246079 & 69162 & 44468 & 104848 \\
2003 & 626858 & 299112 & 106530 & 332655 & 71339 & 45094 & 104962 \\
2004 & 765502 & 310584 & 196587 & 335317 & 71895 & 76831 & 144324 \\
2006 & 964083 & 353837 & 223859 & 318654 & 51650 & 98113 & 130299 \\
2008 & 1045657 & 372746 & 275318 & 301054 & 45722 & 93218 & 117866 \\
2010 & 1216165 & 422409 & 330865 & 422770 & 97791 & 85251 & 143900 \\
2012 & 1452853 & 471096 & 392296 & 568683 & 130831 & 79885 & 161336 \\
2014 & 1539042 & 539509 & 397308 & 560458 & 153019 & 102859 & 191592 \\
2016 & 1627680 & 562034 & 475663 & 571314 & 262578 & 135643 & 207437 \\
$\mathbf{2 0 1 7}$ & $\mathbf{1 8 2 0 9 7 0}$ & $\mathbf{5 7 9 8 6 0}$ & $\mathbf{5 0 1 3 5 0}$ & $\mathbf{6 2 3 7 5 0}$ & $\mathbf{2 9 9 7 3 1}$ & $\mathbf{1 2 7 0 3 4}$ & $\mathbf{2 0 3 6 2 2}$ \\
$\mathbf{2 0 1 8}$ & $\mathbf{1 9 0 3 3 8 0}$ & $\mathbf{6 0 0 4 4 0}$ & $\mathbf{5 2 7 9 0 0}$ & $\mathbf{6 4 7 5 0 0}$ & $\mathbf{3 4 0 1 6 6}$ & $\mathbf{1 3 2 0 3 6}$ & $\mathbf{2 1 0 1 8 8}$ \\
$\mathbf{2 0 1 9}$ & $\mathbf{1 9 8 5 7 9 0}$ & $\mathbf{6 2 1 0 2 0}$ & $\mathbf{5 5 4 4 5 0}$ & $\mathbf{6 7 1 2 5 0}$ & $\mathbf{3 8 3 8 8 3}$ & $\mathbf{1 3 7 0 3 8}$ & $\mathbf{2 1 6 7 5 4}$ \\
$\mathbf{2 0 2 0}$ & $\mathbf{2 0 6 8 2 0 0}$ & $\mathbf{6 4 1 6 0 0}$ & $\mathbf{5 8 1 0 0 0}$ & $\mathbf{6 9 5 0 0 0}$ & $\mathbf{4 3 0 8 8 2}$ & $\mathbf{1 4 2 0 4 0}$ & $\mathbf{2 2 3 3 2 0}$ \\
$\mathbf{2 0 2 1}$ & $\mathbf{2 1 5 0 6 1 0}$ & $\mathbf{6 6 2 1 8 0}$ & $\mathbf{6 0 7 5 5 0}$ & $\mathbf{7 1 8 7 5 0}$ & $\mathbf{4 8 1 1 6 3}$ & $\mathbf{1 4 7 0 4 2}$ & $\mathbf{2 2 9 8 8 6}$ \\
$\mathbf{2 0 2 2}$ & $\mathbf{2 2 3 3 0 2 0}$ & $\mathbf{6 8 2 7 6 0}$ & $\mathbf{6 3 4 1 0 0}$ & $\mathbf{7 4 2 5 0 0}$ & $\mathbf{5 3 4 7 2 6}$ & $\mathbf{1 5 2 0 4 4}$ & $\mathbf{2 3 6 4 5 2}$ \\
$\mathbf{2 0 2 3}$ & $\mathbf{2 3 1 5 4 3 0}$ & $\mathbf{7 0 3 3 4 0}$ & $\mathbf{6 6 0 6 5 0}$ & $\mathbf{7 6 6 2 5 0}$ & $\mathbf{5 9 1 5 7 1}$ & $\mathbf{1 5 7 0 4 6}$ & $\mathbf{2 4 3 0 1 8}$ \\
$\mathbf{2 0 2 4}$ & $\mathbf{2 3 9 7 8 4 0}$ & $\mathbf{7 2 3 9 2 0}$ & $\mathbf{6 8 7 2 0 0}$ & $\mathbf{7 9 0 0 0 0}$ & $\mathbf{6 5 1 6 9 8}$ & $\mathbf{1 6 2 0 4 8}$ & $\mathbf{2 4 9 5 8 4}$ \\
$\mathbf{2 0 2 5}$ & $\mathbf{2 4 8 0 2 5 0}$ & $\mathbf{7 4 4 5 0 0}$ & $\mathbf{7 1 3 7 5 0}$ & $\mathbf{8 1 3 7 5 0}$ & $\mathbf{7 1 5 1 0 7}$ & $\mathbf{1 6 7 0 5 0}$ & $\mathbf{2 5 6 1 5 0}$ \\
\hline & & & & & & & \\
\hline
\end{tabular}

When Table 4 was analyzed, the predicted increase rate in the amount of wastewater treated from 2016 to 2025 could be seen. The predicted increase rates were as 52.38\% in Marmara Region, 32.47\% in Aegean Region, 50.05\% in Mediterranean Region, $42.44 \%$ in Central Anatolia, 172.34\% in Black Sea Region, 23.15\% in Eastern Anatolia Region and 23.48\% in Southeast Anatolia Region. The highest increase in the amount of wastewater was predicted to be in the Black Sea region and the lowest increase rate of wastewater would be in the Eastern Anatolia Region. When Table 2 and Table 4 were compared, it had seen that the increase in the amount of wastewater to be treated would increase to a very high value of $172.34 \%$ in 2025 in the Black Sea Region. It was observed that the rate of increase in population growth rate and the increase in the amount of wastewater to be increased in Eastern Anatolia Region had the lowest rate among the seven geographical regions. In addition, the rate of increase in the amount of treated wastewater would be much higher than the population growth rate in all regions. The equations of prediction of the wastewater amounts to be treated according to 
the population of seven geographical regions between 2018 and 2025 were obtained as at Table 5 with the curve fitting algorithm applied in Matlab environment. In these equations, $T W W$ stands for Treated Wastewater (thousand $\mathrm{m}^{3}$ ) and $P$ stands for population.

Table 5. Treated wastewater equations by population for each region and the R-squared values

\begin{tabular}{cc}
\hline Region & Treated Wastewater Equation $($ by population) \\
\hline Marmara & $193.7 \times$ population $-3.019 \times 10^{9}$ \\
Aegean & $0.1852 \times$ population $-1.35 \times 10^{6}$ \\
Mediterranean & $0.2022 \times$ population $-1.577 \times 10^{6}$ \\
Central Anatolian & $0.1615 \times$ population $-1.543 \times 10^{6}$ \\
Black Sea & $1.516 \times$ population $-1.047 \times 10^{7}$ \\
East Anatolian & $0.1902 \times$ population $-1.015 \times 10^{6}$ \\
Southeast Anatolian & $0.04218 \times$ population $-1.645 \times 10^{5}$ \\
\hline
\end{tabular}

\subsection{Lighting Consumption Energy}

Lighting is the applied light to see the objects in a region and the environment of these objects. Lighting in cities is of great importance. The biggest aim of lighting in the cities is to make streets bright. Besides, the fact that a province is bright at night allows the values such as the historical monuments belonging to that province to be visible at night. The energy used for lighting purposes in Turkey corresponds to $2.62 \%$ of the total electrical energy consumed. This ratio had been obtained from the average of the energy consumption percentages (TUIK, 2019) of 48 years between 1970 and 2017. Considering the lighting consumption data the years 2000 and 2017 (TUIK, 2019), total consumption values between 2018 and 2025 were obtained by using curve fitting algorithm written in Matlab environment. This curve was a curve of total electricity consumption in Turkey. The graph showing this curve was as in Figure 4. In the resulting polynomial equation, the R-square value was 0.9874 and the equation was "Lighting Energy Consumption $=8791$ * year$1,749 * 10^{7 ”}$.

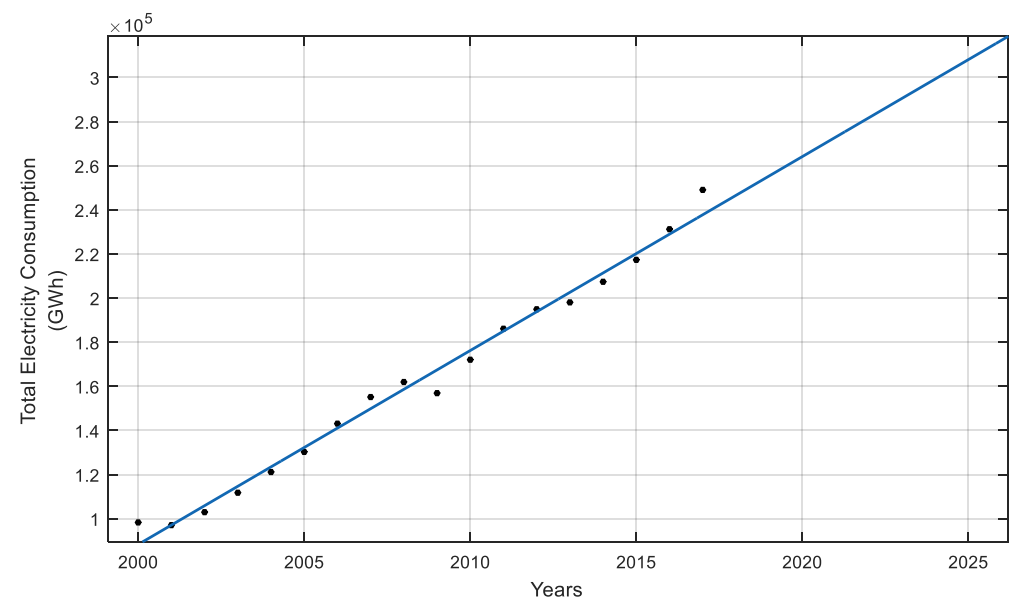

Figure 4. Total electricity consumption (Turkey)

Figure 4 shows the values of total electricity consumption in Turkey. However, in this study, it is necessary to find out how much electricity is consumed for lighting purposes. For this, the percentages rate of the data in Table 6 were used. In order to find out how much of the total electrical energy consumed between 2018 and 2025 was used in lighting, "Forecast Sheet" application in Excel was used. Percentiles of the years 2018-2025 have been found through this application. The energy consumed with the aim of lighting between the years 2018 and 2025 was found by the ratio of total consumed energies to these percentages. However, in this study, it was necessary to rate the total lighting energies according to regions as seven geographical regions were studied. 
Table 6. Total consumed electrical energy values and electrical energy values consumed with the purpose of lighting (TUIK, 2019)

\begin{tabular}{cccccccc}
\hline Year & $\begin{array}{c}\text { Total } \\
\text { Consumption } \\
(\mathbf{G W h})\end{array}$ & $\begin{array}{c}\text { Lighting } \\
\text { Consumption } \\
\text { Percentage } \\
(\boldsymbol{\%})\end{array}$ & $\begin{array}{c}\text { Lighting } \\
\text { Consumption } \\
(\mathbf{M W h})\end{array}$ & Year & $\begin{array}{c}\text { Total } \\
\text { Consumption } \\
\text { (GWh) }\end{array}$ & $\begin{array}{c}\text { Lighting } \\
\text { Consumption } \\
\text { Percentage } \\
(\boldsymbol{\%})\end{array}$ & $\begin{array}{c}\text { Lighting } \\
\text { Consumption } \\
\text { (MWh) }\end{array}$ \\
\hline 2000 & 98296 & 4.6 & 4521616 & 2013 & 198045 & 1.9 & 3762855 \\
2001 & 97070 & 5.0 & 4853500 & 2014 & 207375 & 1.9 & 3940125 \\
2002 & 102948 & 5.0 & 5147400 & 2015 & 217312 & 1.9 & 4128928 \\
2003 & 111766 & 4.5 & 5029470 & 2016 & 231204 & 1.8 & 4161667 \\
2004 & 121142 & 3.7 & 4482254 & 2017 & 249023 & 1.8 & 4482407 \\
2005 & 130263 & 3.2 & 4168416 & $\mathbf{2 0 1 8}$ & $\mathbf{2 5 0 2 3 8}$ & $\mathbf{1 . 8}$ & $\mathbf{4 4 2 9 2 1 3}$ \\
2006 & 143071 & 2.8 & 4005988 & $\mathbf{2 0 1 9}$ & $\mathbf{2 5 9 0 2 9}$ & $\mathbf{1 . 7}$ & $\mathbf{4 5 0 7 1 0 5}$ \\
2007 & 155135 & 2.6 & 4033510 & $\mathbf{2 0 2 0}$ & $\mathbf{2 6 7 8 2 0}$ & $\mathbf{1 . 7}$ & $\mathbf{4 5 7 9 7 2 2}$ \\
2008 & 161948 & 2.5 & 4048700 & $\mathbf{2 0 2 1}$ & $\mathbf{2 7 6 6 1 1}$ & $\mathbf{1 . 7}$ & $\mathbf{4 6 4 7 0 6 5}$ \\
2009 & 156894 & 2.5 & 3922350 & $\mathbf{2 0 2 2}$ & $\mathbf{2 8 5 4 0 2}$ & $\mathbf{1 . 7}$ & $\mathbf{4 7 0 9 1 3 3}$ \\
2010 & 172051 & 2.2 & 3785122 & $\mathbf{2 0 2 3}$ & $\mathbf{2 9 4 1 9 3}$ & $\mathbf{1 . 6}$ & $\mathbf{4 7 6 5 9 2 7}$ \\
2011 & 186100 & 2.1 & 3908100 & $\mathbf{2 0 2 4}$ & $\mathbf{3 0 2 9 8 4}$ & $\mathbf{1 . 6}$ & $\mathbf{4 8 1 7 4 4 6}$ \\
2012 & 194923 & 2.0 & 3898460 & $\mathbf{2 0 2 5}$ & $\mathbf{3 1 1 7 7 5}$ & $\mathbf{1 . 6}$ & $\mathbf{4 8 6 3 6 9 0}$ \\
\hline
\end{tabular}

Then, consumption values of each province were obtained as percentage using lighting consumption data covering three years (20152017) of 81 cities from EPDK Electricity Market Development Reports (EPDK, 2019). For each province, the lighting consumption amounts between 2018 and 2025 were calculated using these lighting consumption percentages. The "Forecast Sheet" application was also used in Excel. The values obtained in Table 6 were applied to the provinces and the lighting consumption values of the 81 provinces between 2018 and 2025 were found. Then, energy consumption values of the cities in each geographical region were collected and total energy consumption of the regions were obtained. At the end of these studies, the current (2015-2017) and predicted (2018-2025) lighting energy consumption values obtained for the seven geographical regions were as in Table 7.

Table 7. Current and predicted lighting energy consumption values between 2015 and 2025 (EPDK, 2019)

\begin{tabular}{|c|c|c|c|c|c|c|c|c|c|c|c|}
\hline \multirow[t]{2}{*}{ Region/Year } & \multicolumn{3}{|c|}{$\begin{array}{l}\text { Current Lighting Consumption } \\
\text { (MWh) }\end{array}$} & \multicolumn{8}{|c|}{ Predicted Lighting Consumption (MWh) } \\
\hline & 2015 & 2016 & 2017 & 2018 & 2019 & 2020 & 2021 & 2022 & 2023 & 2024 & 2025 \\
\hline Marmara & 1001421.9 & 1030397.2 & 1025983.7 & 1043965.5 & 1054275 & 1062953 & 1070219 & 1075632 & 1079959 & 1082962 & 1084603 \\
\hline Aegean & 874784.5 & 608821.2 & 635201.0 & 634263.3 & 634212.8 & 632917.6 & 635253.8 & 632031.6 & 627672.6 & 632048,9 & 660002.7 \\
\hline Mediterranean & 482066.8 & 554401.9 & 527757.5 & 553208.7 & 568859.8 & 584372.5 & 599006.7 & 613666.0 & 627672.6 & 640720.3 & 653679.9 \\
\hline $\begin{array}{l}\text { Central } \\
\text { Anatolia }\end{array}$ & 817509.3 & 823669.7 & 849513.4 & 859710.2 & 868582.2 & 876100.8 & 882477.6 & 887737.5 & 891704.9 & 894599.7 & 896378.1 \\
\hline Black Sea & 659570.4 & 667570.5 & 681238.3 & 683870.5 & 685143.1 & 689248.2 & 692877.4 & 695134.0 & 682480.7 & 688894.8 & 696966.8 \\
\hline $\begin{array}{l}\text { Eastern } \\
\text { Anatolia }\end{array}$ & 268202.7 & 265391.2 & 308506.3 & 306058.6 & 308799.8 & 311421.1 & 313212.2 & 315106.9 & 315981.0 & 316987.9 & 317112.6 \\
\hline $\begin{array}{l}\text { South Eastern } \\
\text { Anatolia }\end{array}$ & 205919.7 & 267963.4 & 309047.3 & 348136.1 & 387223.4 & 427288.1 & 467959.4 & 508652.3 & 549988.0 & 591582.4 & 632766.1 \\
\hline
\end{tabular}

When Table 7 was examined, it has been see that the highest energy consumption was in Marmara Region and the lowest in Eastern Anatolia Region. When 2017 year compared with 2025 year, it has been see that the lighting energy consumption increased as $5.71 \%$ in the Marmara Region, 3.9\% in the Aegean Region, 23.86\% in the Mediterranean Region, $5.52 \%$ in the Central Anatolia Region, $2.31 \%$ in the Black Sea Region, 2.79\% in the Eastern Anatolia Region and 104.75\% in the Southeastern Anatolia Region. The lowest lighting consumption energy prediction was realized in the Black Sea Region. When Table 2 and Table 7 were compared, it has been see that the amount of lighting energy consumption lags behind population growth rate in Marmara, Aegean, Central Anatolia and Black Sea Regions. In the Mediterranean, Eastern Anatolia and Southeastern Anatolia Regions, it has been see that lighting energy consumption rates were obtained at rates above the population increase. The equations of prediction of the lighting consumption 
amounts of the seven geographical regions between the years 2018 and 2025 were obtained as at the Table 8 with the curve fitting algorithm applied in Matlab environment. In these equations, IEC stands for Lighting Energy Consumption (MWh) and $P$ stands for Population.

Table 8. Lighting consumption energy equations for each region by population

\begin{tabular}{cc}
\hline Region & Lighting Consumption Energy (by population) \\
\hline Marmara & $0.01363 \times$ population $+7.025 \times 10^{5}$ \\
Aegean & $0.01582 \times$ population $+4.632 \times 10^{5}$ \\
Mediterranean & $0.1092 \times$ population $-5.823 \times 10^{5}$ \\
Central Anatolian & $0.0349 \times$ population $+3.907 \times 10^{5}$ \\
Black Sea & $0.03214 \times$ population $+4.564 \times 10^{5}$ \\
East Anatolian & $0.05851 \times$ population $+4.524 \times 10^{4}$ \\
Southeast Anatolian & $0.2617 \times$ population $-1.978 \times 10^{6}$ \\
\hline
\end{tabular}

\subsection{Hydroelectric Generation}

Hydropower is the force generated by the movement of water bodies. There must be three things to generate hydropower. These are flowing water, hydraulic turbines and generators. The hydraulic turbine converts the energy of flowing water into mechanical energy by turning the impeller of the hydraulic turbine connected to a generator. The generator converts this mechanical energy into electrical energy. When a magnet passes through a conductor, it causes the flow of electrons. Thus, electricity generation is realized. In a large generator, electromagnets are formed by circulating direct current through wire rings wrapped around magnetic steel lamination stacks known as field posts. When the rotor rotates, it causes the field poles to cross the conductors mounted on the stator. This leads to electrical output and voltage to the generator output terminals (Hydroelectric-1, 2019, Hydroelectric-2, 2019). The natural technical, economic and environmental benefits of hydroelectric energy are thought to make a significant contribution to the future energy of the world, especially in developing countries. Hydroelectric power is one of the renewable energy sources that are of great importance in the world's total electricity supply. Hydropower is both a natural energy source and economic. Hydroelectric power plants can help balance supply and demand in electrical energy. They can also play a stabilizing role in the event of interruptions in electricity generation, such as wind and solar energy. Hydropower is associated with the flow of water and the flow of water is the fuel of a hydroelectric power plant (Zhou et al., 2015, Manzano-Agugliaro et al., 2017). The power generated by a turbine was calculated used Equation (1) (Nasir, 2014).

$\mathrm{P}_{t}=\rho * g * H_{n} * Q * \eta_{t}(w a t t)$

where the $\mathrm{P}_{t}$ is the power generated on the turbine shaft,

$\rho$, water density $\left(1000 \mathrm{~kg} / \mathrm{m}^{3}\right)$,

$H_{n}$, net height $(\mathrm{m})$,

$Q$, water flow rate $\left(\mathrm{m}^{3} / \mathrm{s}\right)$,

$g$, gravitational acceleration constant $\left(9.8 \mathrm{~m} / \mathrm{s}^{2}\right)$

$\eta_{t}$, turbine efficiency $(80-90 \%)$

\section{Results and Discussion}

\subsection{Case Study (Head Height is 3 meters)}

Equation (1) was used to calculate the amount of energy that can be generated according to the amount of treated wastewater to be passed to the wastewater treatment plants. In this study, $\eta$ is the efficiency coefficient and it was accepted as 0,80 . According to this, using the flow values in Table 4, the power values obtained in Marmara Region for 2017 at a height of 3 meters were obtained as follows:

$\mathrm{E}_{t}=1359.49 \mathrm{kWh}$ (hourly),

$\mathrm{E}_{t}=32627.76 \mathrm{kWh}$ (daily),

$\mathrm{E}_{t}=11909132.4 \mathrm{kWh}$ (yearly),

$\mathrm{E}_{t}=0.0119 \mathrm{TWh}$ (yearly), 
Similarly, if the predicted electricity generation values of both the other regions and the following years were calculated, the power values in Table 9 were obtained. Accordingly, the predicted annual electricity generation values that can be obtained from wastewater treatment plants in each region between the years of 2017 and 2025 in Turkey at Table 9.

Table 9. Predicted power values for the coming years at a height of 3 meters (Regional)

\begin{tabular}{cccccccc}
\hline \multicolumn{7}{c}{ Predicted Power (TW/year) } \\
\hline Years & Marmara & Aegean & Mediterranean & $\begin{array}{c}\text { Central } \\
\text { Anatolia }\end{array}$ & Black Sea & $\begin{array}{c}\text { Eastern } \\
\text { Anatolia }\end{array}$ & $\begin{array}{c}\text { South Eastern } \\
\text { Anatolia }\end{array}$ \\
\hline 2017 & 0.0119 & 0.0038 & 0.0033 & 0.0041 & 0.0020 & 0.0008 & 0.0013 \\
$\mathbf{2 0 1 8}$ & $\mathbf{0 . 0 1 2 4}$ & $\mathbf{0 . 0 0 3 9}$ & $\mathbf{0 . 0 0 3 5}$ & $\mathbf{0 . 0 0 4 2}$ & $\mathbf{0 . 0 0 2 2}$ & $\mathbf{0 . 0 0 0 9}$ & $\mathbf{0 . 0 0 1 4}$ \\
2019 & 0.0130 & 0.0041 & 0.0036 & 0.0044 & 0.0025 & 0.0009 & 0.0014 \\
2020 & 0.0135 & 0.0042 & 0.0038 & 0.0045 & 0.0028 & 0.0009 & 0.0015 \\
2021 & 0.0141 & 0.0043 & 0.0040 & 0.0047 & 0.0031 & 0.0010 & 0.0015 \\
2022 & 0.0146 & 0.0045 & 0.0041 & 0.0049 & 0.0035 & 0.0010 & 0.0015 \\
2023 & 0.0151 & 0.0046 & 0.0043 & 0.0050 & 0.0039 & 0.0010 & 0.0016 \\
2024 & 0.0157 & 0.0047 & 0.0045 & 0.0052 & 0.0043 & 0.0011 & 0.0016 \\
$\mathbf{2 0 2 5}$ & $\mathbf{0 . 0 1 6 2}$ & $\mathbf{0 . 0 0 4 9}$ & $\mathbf{0 . 0 0 4 7}$ & $\mathbf{0 . 0 0 5 3}$ & $\mathbf{0 . 0 0 4 7}$ & $\mathbf{0 . 0 0 1 1}$ & $\mathbf{0 . 0 0 1 7}$ \\
\hline
\end{tabular}

When the amount of electrical energy obtained from wastewater treatment plants in Table 9 was examined from 2017 to 2025 years, it was seen that the highest power generation was in Marmara Region and the lowest power generation was in Eastern Anatolia Region. When the electrical power values that could be obtained from wastewater treatment plants were examined between the years of 2017 and 2025, it had been see that there were increases in different rates in each region. These increase rates were 36.13\% in Marmara Region, 28.95\% in Aegean Region, 42.42\% in Mediterranean Region, 29.27\% in Central Anatolia Region, 135\% in Black Sea Region, 37.5\% in Eastern Anatolia Region and 30.77\% in Southeast Anatolia Region. It was predicted that the highest annual increase rate would be in the Black Sea Region and the lowest annual average rate of increase would be in Aegean Region. At the end of all these studies, the values of Figure 5 would be obtained by examining the ratio of electricity energy generated from wastewater treatment plants in each region to the ratio of energy consumption of lighting in that region. Figure 5 shows these coverage rates for both 2018 and 2025.

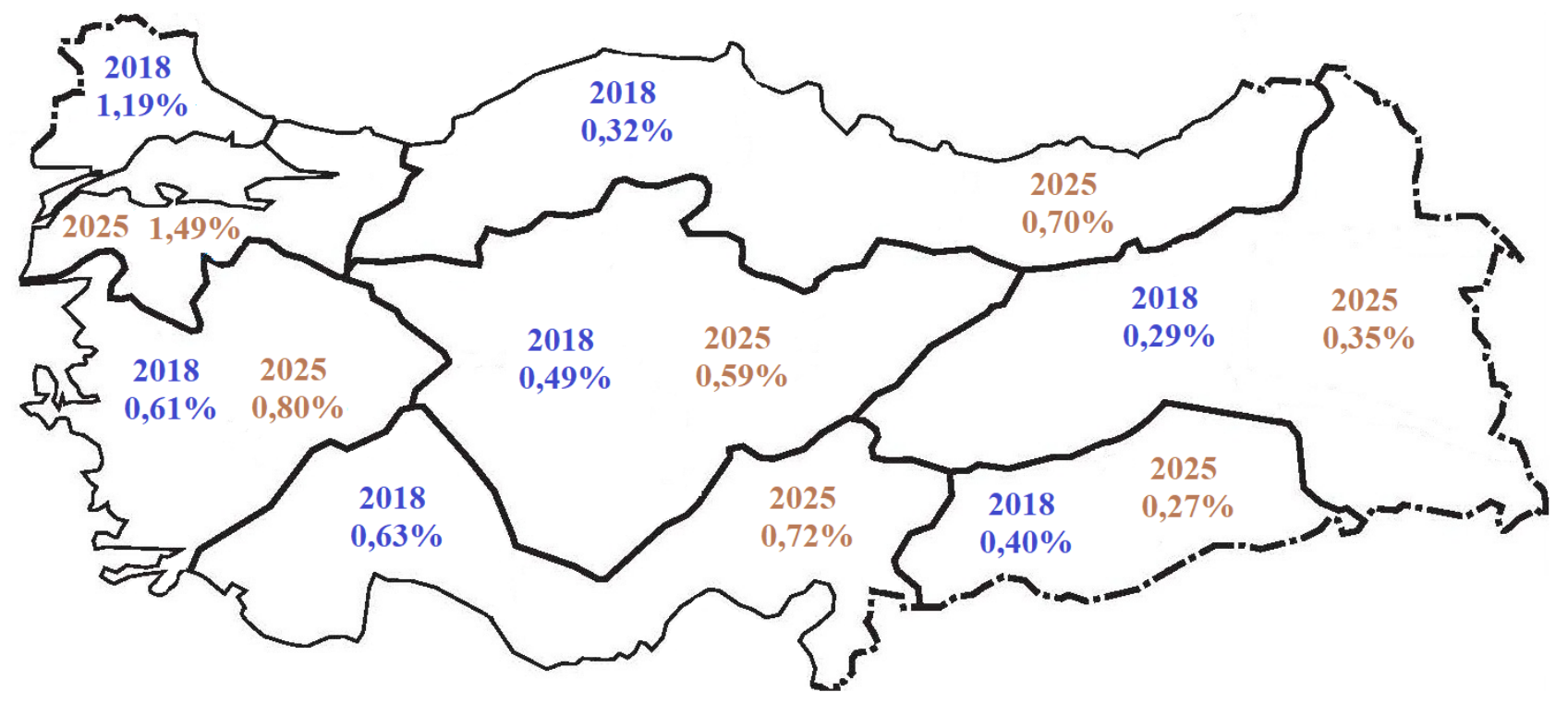

Figure 5. The coverage ratio of wastewater treatment plant hydroelectric generation to urban lighting consumption energy as regional (for 2018 and 2025) 
In 2018, the highest coverage rate was realized in Marmara Region, while the lowest coverage rate was in Eastern Anatolia. In 2025, the highest coverage ratio was in the Marmara Region while the lowest coverage rate was in Southeastern Anatolia. From 2018 to 2025 , the coverage ratio of wastewater treatment plant hydropower to lighting consumption increased up to $0.31 \%$ difference Marmara Region. When other regions were examined, respectively, $0.19 \%$ in Aegean Region, $0.09 \%$ in Mediterranean Region, $0.10 \%$ in Central Anatolia Region, $0.38 \%$ in Black Sea Region and $0.05 \%$ in Eastern Anatolia Region. In the Southeastern Anatolia Region, it decreased up to $0.13 \%$. It was predicted that the highest increase would be realized in Black Sea Region from 2018 to 2025.

In this study, unlike other studies, the curve fitting method written in Matlab environment was used to obtain predicted values of population, treated wastewater and lighting energy consumption parameters. In addition, a study was conducted on the use of electrical energy to be obtained from treated wastewater in urban lighting. Chae et al. (2015) calculated an annual electricity generation of 68.1 MWh in a municipal WWTP for 4.3 meters of head height. In this study, in the calculations made for 2018 at a height of 3 meters, an annual electricity generation of $2200 \mathrm{MWh}$ for the Black Sea region was calculated. There are 18 provinces in the Black Sea region. The average corresponds to $122 \mathrm{MWh}$ of electrical energy for each province. It was seen that the calculations made were compatible with each other.

\section{Conclusions}

This study primarily was conducted both hydroelectric generation predicts of wastewater treatment plants in Turkey and total lighting energy consumption values of the cities in each region were predicted. Then, the coverage ratio of these predicted values to each other was determined. For these, predictions were made separately for Turkey's seven geographical regions. In studies, it was assumed that head height 3 meters. With the data obtained, the coverage ratio of the electricity generation of the wastewater treatment plant in each region to the urban lighting consumption was obtained. When the amount of electrical energy obtained from wastewater treatment plants was examined from 2017 to 2025 year, it has been seen that the highest electrical energy generation was in Marmara Region and the lowest electrical energy generation was in Eastern Anatolia Region. In the period from 2017 to 2025 year, it was predicted that electricity generation rates would increase by $36.21 \%$ in Marmara Region, 28.39\% in Aegean Region, $42.37 \%$ in Mediterranean Region, 30.46\% in Central Anatolia, 138.58\% in Black Sea Region, 31.50\% in Eastern Anatolia Region and 25.80\% in Southeast Anatolia Region When the annual increases were examined, the highest average increase was $11.49 \%$ in the Black Sea Region and the lowest average increase was $2.91 \%$ in Southeastern Anatolia Region. When both the annual increases and the years between 2018 and 2025 were compared, it has been seen that the most remarkable rate of increase has been in the Black Sea region.

Significant results were also obtained in the study on the rate of electrical energy generated from wastewater treatment plants in a region to cover the total lighting energy consumed in the cities in that region. According to these results, the highest coverage ratio in 2018 was realized in Marmara Region, while the lowest coverage rate was in Eastern Anatolia. In 2025, the highest coverage ratio was in the Marmara Region while the lowest coverage rate was in Southeastern Anatolia. From 2018 to 2025 year, the coverage ratio of wastewater treatment plant hydropower to lighting consumption increased by $0.31 \%$ difference Marmara Region. When other regions were examined, respectively, 0.19\% in Aegean Region, 0.09\% in Mediterranean Region, $0.10 \%$ in Central Anatolia Region, $0.38 \%$ in Black Sea Region and $0.05 \%$ in Eastern Anatolia Region. In the Southeastern Anatolia Region, it decreased by 0.13\%. It was predicted that the highest increase would be realized in Black Sea Region from 2018 to 2025 . However, some characteristics of the system (changes in flow rate, climate etc.) were not modeled in the prediction model here. There may be some deviations in the predictions depending on these characteristics which were not considered. Accordingly, considering the predicted electricity generation values obtained from this study, it can be considered as a secondary source for meeting the future electricity needs of cities.

\section{Referanslar}

Abbas, A.I., Qandil, M.D., Al-Haddad, M.R., Saravani, M.S. (2018). Amano, R.S., Utilization of Hydro-Turbines in Wastewater Treatment Plants. ASME 2018 12th International Conference on Energy Sustainability collocated with the ASME 2018 Power Conference and the ASME 2018 Nuclear Forum, ES2018-7349 (V001T01A003) 7 pages. https://doi.org/10.1115/ES2018-7349.

Ak, M., Kentel, E. \& Kucukali, S. (2017). A fuzzy logic tool to evaluate low-head hydropower technologies at the outlet of wastewater treatment plants. Renewable and Sustainable Energy Reviews, 68 (1) 727-737. https://doi.org/10.1016/j.rser.2016.10.010.

Baran, B. (2019). Sınır Değerler Arasında Kalan Evsel Atıksu Numune Analizi Sonucunun Aşııı Öğrenme Makineleri İle Sinıflandırılması. Journal of Engineering Sciences and Design, 7(1) 18-25, (2019). https://doi.org/10.21923/jesd.457085.

Berger, V., Niemann, A., Frehmann, T., Brockmann, H. (2013). Advanced energy recovery strategies for wastewater treatment plants and sewer systems using small hydropower. Water Utility Journal, 5, 15-24.

Bhandari, B., Poudel, S.R., Lee, K.T. \& Ahn, S.H. (2014). Mathematical Modeling of Hybrid Renewable Energy System: A Review on Small Hydro-Solar-Wind Power Generation. International Journal of Precision Engineering and Manufacturing-Green Technology, 1(2), 157-173. doi: 10.1007/s40684-014-0021-4. 
Bousquet, C., Samora, I., Manso, P., Rossi, L., Heller, P. \& Schleiss, A.J. (2017). Assessment of hydropower potential in wastewater systems and application to Switzerland. Renewable Energy, 113, 64-73. https://doi.org/10.1016/j.renene.2017.05.062.

Chae, K.J., Kim, I.S., Ren, X. \& Cheon, K.H. (2015). Reliable energy recovery in an existing municipal wastewater treatment plant with a flow-variable micro-hydropower system. Energy Conversion and Management, 101, 681-688. https://doi.org/10.1016/j.enconman.2015.06.016.

$\begin{array}{lllllll}\text { Curve } & \text { Fitting. } & 2018 . & \text { Curve } & \text { Fitting } & \text { Method. } & \text { Retrieved }\end{array}$ www.yildiz.edu.tr/ nguzel/Egri_Uydurma_ve_En_Kucuk_Kareler_Yontemi.docx.

EPDK. (2019). Republic of Turkey Energy Market Regulatory Authority, Development Reports, Retrieved from https://www.epdk.org.tr/Home/En.

Frijns, J., Hofman, J., Nederlof, M., 2013. The potential of (waste)water as energy carrier. Energy Conversion and Management, 65, 357-363. https://doi.org/10.1016/j.enconman.2012.08.023.

Gu, Y., Li, Y., Li, X., Luo, P., Wang, H., Robinson, Z.P., Wang, X., Wu, J. \& Li, F. (2017). The feasibility and challenges of energy self-sufficient wastewater treatment plants. Applied Energy, 204, 1463-1475. https://doi.org/10.1016/j.apenergy.2017.02.069.

Hydroelectric-1. (2019). Hydroelectric Power. Retrieved from https://www.usgs.gov/special-topic/water-scienceschool/science/hydroelectric-power-how-it-works?qt-science_center_objects=0\#qt-science_center_objects.

Hydroelectric-2. (2019). Hydroelectric Power. Retrieved from https://www.conserve-energyfuture.com/howhydropowerplantsworks.php.

Hydroelectric-3. (2019). Principle of hydropower Generation. Retrieved from https://www.brighthubengineering.com/fluidmechanics-hydraulics/7066-principle-of-hydropower-generation.

Hydroelectric-4. (2019). Hydroelectric Power. Reclamation Managing Water in the West. Retrieved from https://www.usbr.gov/power/edu/pamphlet.pdf.

Kose, F \& Kaya, M.N. (2013). Analysis on meeting the electric energy demand of an active plant with a wind-hydro hybrid power station in Konya, Turkey: Konya water treatment plant. Renewable Energy, 55, 196-201. https://doi.org/10.1016/j.renene.2012.12.047.

Kollmann, R., Neugebauer, G., Kretschmer, F., Truger, B., Kindermann, H., Stoeglehner, G., Ertl, T. \& Narodoslawsky, M. (2017). Renewable energy from wastewater - Practical aspects of integrating a wastewater treatment plant into local energy supply concepts. Journal of Cleaner Production, 155, 119-129. https://doi.org/10.1016/j.jclepro.2016.08.168.

Manzano-Agugliaro, F., Taher, M., Zapata-Sierra, A., Juaidia, A. \& Montoya, F.G., (2017). An overview of research and energy evolution for small hydropower in Europe. Renewable and Sustainable Energy Reviews, 75, 476-489. https://doi.org/10.1016/j.rser.2016.11.013.

Nasir, B.A. (2014). Design Considerations Of Micro-Hydro-ElectricPowerPlant, The International Conference on Technologies and Materials for Renewable Energy. Environment andSustainability, TMREES14. Energy Procedia, 1-9. https://doi.org/10.1016/j.egypro.2014.06.003.

Nimje, A.A. \& Dhanjode, G. (2015). Pico-Hydro-Plant for Small Scale Power Generation in Remote Villages. IOSR Journal of Environmental Science. Toxicology and Food Technology (IOSR-JESTFT), 9(1)(3) 59-67.

Power, C., McNabola, A. \& Coughlan, P. (2014). Development of an evaluation method for hydropower energy recovery in wastewater treatment plants: Case studies in Ireland and the UK. Sustainable Energy Technologies and Assessments, 7, 166-177. https://doi.org/10.1016/j.seta.2014.06.001.

Tamrakar, A., Pandey, S.K. \& Dubey, S.C. (2015). Hydro Power Opportunity in the Sewage Waste Water. American International Journal of Research in Science. Technology, Engineering \&Mathematics, 10 (2) 179-183.

TUIK. (2019). Turkish Statistical Institute. Turkey's population and wastewater amount of data. Retrieved from www.turkstat.gov.tr.

Yah, N.F., Oumer, A.N. \& Idris, M.S. (2017). Small scale hydro-power as a source of renewable energy in Malaysia: A review. Renewable and Sustainable Energy Reviews, 72, 228-239. https://doi.org/10.1016/j.rser.2017.01.068. 
Zarfl, C., Lumsdon, A.E., Berlekamp, J., Tydecks, L. \& Tockner, K. (2015). A global boom in hydropower dam construction. Aquatic Sciences, 77(1) 161-170. doi: 10.1007/s00027-014-0377-0.

Zhou, D. \& Deng, Z.D. (2017). Ultra-low-head hydroelectric technology: A review. Renewable and Sustainable Energy Reviews, 78, 23-30. https://doi.org/10.1016/j.rser.2017.04.086.

Zhou, Y., Hejazi, M., Smith, S., Edmonds, J., Li, H., Clarke, L., Calvin, K. \& Thomson, A. (2015). A Comprehensive View of Global Potential for Hydro-generated Electricity. Energy and Environmental Sciences, 9. doi: 10.1039/C5EE00888C. 